\title{
KUALITAS GENTENG TANAH LIAT DENGAN CAMPURAN SERBUK KACA
}

\author{
Faiz Mudhofir ${ }^{1,2, a)}$, Sulhadi ${ }^{1, b)}$, Mahardika Prasetya Aji ${ }^{1, c)}$ \\ ${ }^{1}$ Prodi Pendidikan Fisika PPS UNNES, Kampus Pascasarjana UNNES Jl. Kelud Utara III Semarang 50237 \\ ${ }^{2}$ MAS Tahfidz Yanbu'ul Qur'an Kab.Kudus Jl. Rahtawu-Menawan 59534 \\ Email: ${ }^{a)}$ faizmudhofir@icloud.com ${ }^{\text {b) }}$ sulhadipati@yahoo.com ${ }^{\text {c) }}$ mahardika190@ gmail.com
}

\begin{abstract}
Abstrak
Pertambahan populasi manusia yang semakin meningkat sebanding dengan kebutuhannya. Pemenuhan kebutuhan sehari-hari meningkatkan jumlah sampah rumah tangga. Limbah botol kaca merupakan salah satu limbah yang perlu dimanfaatkan secara optimal. Oleh sebab itu perlu adanya inovasi pemanfaatan limbah botol kaca tersebut. Satu dari bentuk inovasinya adalah pemanfaatan serbuk kaca untuk bahan campuran pada pembuatan genteng tanah liat home industry. Untuk itu pada penelitian ini memanfaatkan limbah botol kaca sebagai campuran genteng dengan komposi campuran $0 \%, 5 \%, 10 \%$, $15 \%$, dan 20\% dari massa keseluruhan genteng tanah liat. Mutu genteng dibandingkan antara keadaan normal dan campuran dilihat dari variabel daya serap air dan kuat tekan genteng. Pada penelitian ini diperoleh hasil bahwa semakin banyak campuran serbuk kaca maka genteng memiliki porositas yang semakin kecil/memiliki daya serap air lebih rendah. Keadaan campuran terbaik diperoleh pada campuran $15 \%$ yaitu sebesar $8,57 \%$. Penambahan serbuk kaca mempengaruhi gaya tarik partikel tanah liat pada genteng sehingga pada komposisi tertentu dapat menambah kuat daya tekan tetapi pada komposisi yang berlebih justru mengurangi kuat daya tekan.
\end{abstract}

Kata-kata kunci: genteng tanah liat, serbuk kaca, kuat daya tekan, daya serap air.

\begin{abstract}
The growth of human population is proportional to its needs. Fulfilling daily needs increases the amount of household waste. Glass waste is one of the waste that needs to be utilized optimally. Therefore it is necessary to invent the utilization of glass waste. One of its innovative forms is the use of glass powders for mixed materials on the manufacturing of clay tile home industry. Therefore, in this study researchers will use glass waste as a mixture of tile with mixed compositions of $0 \%, 5 \%, 10 \%, 15 \%$, and $20 \%$ of the overall mass of clay tile. The quality of this tile will be compared between the normal and mixed one, it would be seen from the variable water absorbtion and tile strength. The results stated that the more mixture of glass powder, the tile has a smaller porosity / has a lower water absorbtion. The best mixture was obtained in a $15 \%$ mixture of $8.57 \%$. The addition of the glass powder affects the tensile force of the clay particles in the tile, so in certain compositions it is possible to increase the compressive strength but in the excess composition it reduces the compressive strength.
\end{abstract}

Keywords: clay tile, glass powder, compressive strength, absorbtion.

\section{PENDAHULUAN}

Genteng merupakan bagian penutup suatu bangunan yang melingkupi permukaan bagian di bawahnya dengan susunan saling bertindih (overlapping) yang ditopang kayu ataupun baja ringan. Atap dapat dibuat dari berbagai jenis bahan seperti kayu, tanah liat, kaca, plastik, asbes, dan seng tergantung kebutuhan dan biaya pembangunan. Genteng merupakan salah satu komponen penting 
suatu bangunan untuk melindungi bangunan dari suhu, hujan dan fungsi lainnya. kualitas genteng yang optimal berarti memiliki daya serap air seminimal mungkin. Kolawole menyatakan untuk mendapat genteng dengan daya serap tinggi dapat dilakukan memvariasi bentuk genteng yang bergelombang [1].

Kualitas genteng yang lain ditentukan dari bahan dan suhu pembakaran, karena hal tersebut akan menentukan daya serap air dan daya tekan genteng. Ouahabi dalam penelitiannya menyatakan pada suhu pembakaran yang mencapai $1000^{\circ} \mathrm{C}$ terjadi pemadatan yang sangat baik [2].

Perkembangan produksi genteng menghasilkan produk yang bervariasi. Corak dan warna, bentuk, hingga kuat daya tekan menjadi inovasi dari para produsen. Berbagai upaya untuk mencetak genteng dengan kualitas terbaik selalu dilakukan. Salah satu dari bentuk upaya menghasilkan genteng adalah dengan memberi komposisi campuran dalam pembuatannya. Pemanfaatan kaca, sampah organik, semen, maupun pasir memungkinkan untuk menjadi campuran komposisi genteng.

Syarat Mutu Genteng Menurut Standar Nasional Indonesia menurut Standar Nasional Indonesia (SNI) 03-2095-1998, meliputi :

1) Sifat Tampak

Genteng harus memiliki permukaan atas yang mulus, tidak terdapat retak, atau cacat lain yang mempengaruhi sifat pemakaiannya.

2) Penyerapan Air

Penyerapan air maksimal $20 \%$

3) Kuat Daya Tekan

Genteng keramik harus mampu menahan beban minimum 65-140 kgf.

Melihat permasalahan sampah di tengah masyarakat menjadi sorotan untuk terpecahkan. Limbah rumah tangga, plastik, maupun kaca bertumpukan tanpa manfaat. Limbah sampah tersebut masih terdapat manfaat yang dapat diambil.

Kaca merupakan salah satu sampah akibat dari pemaikan kecap, sirup, botol minuman dan sebagainya. Kaca jendela, lampu, dan botol, tergolong sebagai kaca soda lime yang terbuat dari silika $\left(\mathrm{SiO}_{2}\right)$, campuran batu pasir dengan fluks untuk kemudian dicampur lagi dengan bahan stabilisator supaya kuat.. Produksi awal kaca semula bersifat cair namun memiliki kepadatan tinggi, dan struktur amorf. Atom-atom di dalamnya tidak membentuk suatu jalinan yang beraturan, seperti kristal, atau biasa disebut gelas. Silika ini memiliki diameter nanopertikel [3]

Pemanfaatan kaca sebagai bahan campuran genteng tanah liat cukup beralasan, serbuk kaca memiliki ukuran yang sangat halus dan nilai konduktivitas termal yang tinggi. Keadaan ini memungkinkan untuk mengisi poros atau rongga dalam genteng sehingga genteng akan memiliki nilai porositas yang kecil dan kuat daya tekannya bertambah kuat [4]. Dengan dasar pemikiran tersebut, maka dilakukan penelitian "Kualitas Genteng Tanah Liat dengan Campuran Serbuk Kaca".

\section{METODE PENELITIAN}

Variasi komposisi serbuk kaca pada campuran genteng adalah 0\%, 5\%, 10\%, 15\% dan $20 \%$. Bentuk limbah kaca yang dipakai adalah limbah yang berupa pasir sesuai dengan keadaan aslinya hasil dari pengayaan dengan ukuran $0,2 \mathrm{~mm}$. Benda uji untuk uji kuat tekan digunakan potongan genteng dengan ukuran $3 \mathrm{~cm} \times 3 \mathrm{~cm} \times 1,4 \mathrm{~cm}$ masing-masing sebanyak satu benda uji dan penyerapan air menggunakan genteng dengan ukuran $32 \mathrm{~cm} \times 26 \mathrm{~cm} \times 1,4 \mathrm{~cm}$ dengan benda uji sebanyak 3 buah tiap variasi. Adapun jumlah benda uji yang harus dibuat adalah 15 buah.

Jenis kaca yang digunakan dalam penelitian ini adalah soda lime glass/kaca soda gamping yaitu merupakan $95 \%$ dari semua kaca yang dihasilkan. Kaca ini digunakan untuk membuat segala macam bejana, kaca lembaran, jendela mobil dan barang pecah belah.

Komposisi kaca soda lime adalah sebagai berikut : $\mathrm{SiO}_{2} 75 \%, \mathrm{Na}_{2} \mathrm{O} 15 \%, \mathrm{CaO} 10 \%$. Limbah kaca soda lime ini diperoleh dari hasil daur ulang kaca, dan pecahannya ada yang berupa kerikil, dan ada juga yang berupa pasir. Pasir kaca adalah kaca yang telah dihancurkan dan dapat melalui lubang ayakan sehingga menjadi halus dan bersih untuk selanjutnya menjadi partikel yang dapat berinteraksi dengan tanah liat [5].

Pada penelitian sebelumnya tentang pemanfaatan serbuk kaca pada beton, diperoleh hasil yang menunjukan bahwa beton dengan serbuk kaca dan pengurangan air cakupan tinggi mempunyai 
kuat desak yang tinggi dibanding dengan beton normal [6]. Dalam penelitian yang dilakukan oleh Johanes, dkk., [7] mengenai "Pengaruh Penggunaan Serbuk Kaca Sebagai Bahan Substitusi Agregat Halus Terhadap Sifat Mekanik Beton", kuat tekan beton cenderung menurun dengan semakin tingginya persentase serbuk kaca. Penelitian lain dari Cheila Mothe-Maria Ambrosio [8] tentang pengembangan pengolahan blok keramik berpori dengan bahan pembentuk pori yang berbeda dengan mengadaptasi teknologi Jerman dengan kondisi lingkungan Brasil menghasilkan produk yang terbentuk memiliki kepadatan rendah, porositas tinggi dan kekuatan mekanik yang masuk akal.

\section{Pengujian Daya Serap Air}

Pada saat terbentuk sampel kemungkinan ada udara yang terjebak dalam lapisan agregat atau terjadi karena dekomposisi mineral yang terbentuk akibat perubahan cuaca, sehingga terbentuk lubang atau rongga kecil di dalam butiran agregat (pori). Pori dalam sampel bervariasi dan menyebar di seluruh butiran. Pori-pori mungkin menjadi reservoir air bebas di dalam agregat. Presentase berat air yang mampu diserap agregat dan serat di dalam air disebut daya serapan air, sedangkan banyaknya air yang terkandung dalam agregat dan serat disebut kadar air [9]

Pengujian daya serap air ini mengacu pada ASTM C-20-00-2005 tentang prosedur pengujian, dimana pengujian ini bertujuan untuk menentukan besarnya persentase air yang terserap oleh sampel yang direndam dengan perendaman selama 24 jam. Untuk mendapatkan nilai penyerapan air dihitung dengan menggunakan rumus sebagai berikut :

$$
\text { daya serap }=\frac{\mathrm{M}_{\mathrm{b}}-\mathrm{M}_{\mathrm{k}}}{\mathrm{M}_{\mathrm{k}}} \times 100 \%
$$

di mana: $\mathrm{M}_{\mathrm{b}}=$ massa basah $(\mathrm{kg})$

$\mathrm{M}_{k}=$ massa kering $(\mathrm{kg})$

\section{Kuat Tekan Genteng}

Kuat tekan adalah kemampuan suatu benda untuk menahan gaya tekan atau besarnya beban persatuan luas yang menyebabkan benda uji hancur bila dibebani dengan beban tertentu. Pengujian kuat tekan genteng ini digunakan alat uji tekan dalam satuan kiloNewton sehingga diperlukan perhitungan dengan persamaan:

di mana:

$$
\sigma=\frac{F}{A}
$$

$$
\begin{aligned}
& \sigma=\text { tekanan }(\mathrm{Pa}) \\
& F=\text { gaya maksimum }(\mathrm{N}) \\
& A=\text { luas penampang }\left(\mathrm{m}^{2}\right)
\end{aligned}
$$

\section{HASIL DAN PEMBAHASAN}

\section{Pengambilan data awal}

Pembuatan benda uji dilakukan di home industry genteng tanah liat yang berada di desa Papringan Kecamatan Kaliwungu Kabupaten Kudus dengan sistem produksi menggunakan alat mesin press listrik. Pada tahap awal, data yang dibutuhkan adalah massa mentah dan massa matang genteng. Adapun tabel hasil penimbangan massa mentah dan matang ditunjukkan pada TABEL 1:

TABEL 1. Massa awal genteng.

\begin{tabular}{cccc}
\hline No. & Komposisi Campuran & Massa mentah (kg) & Massa matang $(\mathbf{k g})$ \\
\hline 1. & $0 \%$ & 2,425 & 1,550 \\
2. & $5 \%$ & 2,546 & 1,650 \\
3. & $10 \%$ & 2,657 & 1,700 \\
\hline
\end{tabular}


Massa mentah genteng menunjukkan massa genteng setelah dicetak. Pemberian tambahan komposisi serbuk kaca dilakukan dengan menimbang massa genteng murni kemudian mencari persentase dari massa tersebut sesuai kebutuhan dan menimbangnya kembali. Pada campuran serbuk sebanyak $20 \%$, tahap pengeringan genteng mengalami keretakan yang cukup besar. Keadaan ini disebabkan karena daya ikat tanah liat menurun akibat terlalu banyak campurannya. Karena keadaan tersebut, maka untuk campuran serbuk kaca $20 \%$ tidak ada perlakuan lebih lanjut.

Setelah melalui tahap pengeringan selama kurang lebih tiga hari kemudian pengerikan, maka genteng dibakar sampai pada suhu sekitar $800^{\circ} \mathrm{C}$ selama kurang lebih 15 jam. Hasil pengukuran massa mentah dan matang dapat dilihat pada tabel di atas. Dari tabel di atas dapat diketahui bahwa genteng mengalami penyusutan ukuran pada genteng matang dibandingkan genteng mentah. Penyusutan ukuran ini akibat pemadatan partikel-partikel genteng, baik berupa tanah liat maupun serbuk kaca. Pemadatan partikel ini terjadi akibat rongga genteng yang semula berisi partikel air menjadi kering saat dipanaskan pada suhu yang tinggi sehingga partikel padat akan merapat untuk mengisi rongga tersebut. Akibat penyusutan ini, genteng mengalami pemadatan bahan sehingga bersifat keras dan kuat untuk menahan beban.

Pada penyusutan ukuran genteng, dimungkinkan terjadi pemampatan yang tidak sempurna. Artinya, pada saat pemampatan tidak serta merta partikel penyusun genteng menyusut dalam kondisi yang sangat rapat. Saat proses awal pencetakan genteng tidak cukup kuat atau suhu pembakaran kurang tinggi dapat mengakibatkan terbentuknya rongga dalam genteng. Masalah lain adalah jika dalam komposisi penyusun genteng terdapat partikel dengan ukuran sebesar krikil sekalipun, hal tersebut dapat mengakibatkan retakan akibat pemampatan yang berlebuhan.

\section{Pengujian Daya Serap Air Genteng}

Pengambilan data uji daya serap air genteng adalah dengan mengukur massa sebelum dan sesudah genteng direndam air.

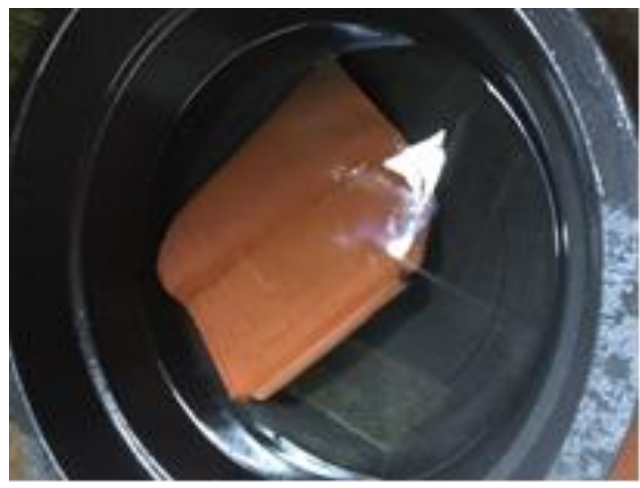

GAMBAR 1. Perendaman genteng di air selama 24 jam

Hasil pengujian daya serap air genteng tanah liat dengan campuran serbuk kaca ditunjukkan pada TABEL 2

TABEL 2. Daya serap air.

\begin{tabular}{ccccc}
\hline No. & Komposisi Campuran & Massa kering (kg) & Massa basah $(\mathbf{k g})$ & Daya Serap Air \\
\hline 1. & $0 \%$ & 1.55 & 2.05 & $32.26 \%$ \\
2. & $5 \%$ & 1.65 & 1.96 & $15.81 \%$ \\
3. & $10 \%$ & 1.70 & 1.93 & $13.53 \%$ \\
\hline
\end{tabular}

Pengujian kualitas genteng yang pertama adalah uji daya serap air. Daya serap air ini menyatakan besar perbandingan massa air yang terserap genteng terhadap massa kering genteng. Tabel di atas 
menunjukkan bahwa semakin besar komposisi campuran serbuk kaca pada genteng menyebabkan porositas genteng menjadi lebih kecil. Nilai daya serap yang lebih kecil menunjukkan keadaan genteng yang semakin rapat.

Keberadaan partikel penyusun genteng yang berbeda dari sifat tanah liat menyebabkan terjadinya dua kemungkinan setelah dipanaskan, yaitu semakin rapat atau terjadi keretakan. Genteng dapat mengalami penyusutan yang baik ketika terdapat partikel asing dengan ukuran yang sangat halus. Dengan penambahan serbuk kaca menyebabkan rongga-rongga genteng terisi padatan serbuk. Kaca merupakan bahan yang memiliki konduktivitas termal yang sangat tinggi. Saat serbuk kaca dipanaskan dengan suhu yang tinggi sekalipun tidak akan mudah mengubah struktur kaca. Keadaan inilah yang menjadikan serbuk kaca mampu mengisi rongga genteng dalam ikatannya dengan tanah liat.

Dari data di atas, pada penambahan campuran sebanyak $15 \%$ memiliki nilai daya serap air terbaik karena hanya menyerap sedikit air. Jika disesuaikan dengan kualitas SNI tentang mutu genteng, maka pada komposisi campuran 5\%, 10\% dan 15\% memenuhi standar karena memiliki daya serap air di bawah $20 \%$, yang secara berturut-turut bernilai $15.81 \%, 13.53 \%$, dan $8,57 \%$.

\section{Uji Kuat Tekan Genteng}

Uji kuat daya tekan dilakukan dengan sampel potongan genteng berukuran $3 \mathrm{~cm} \times 3 \mathrm{~cm} \times 1,4 \mathrm{~cm}$. Pengambilan ukuran ini didasarkan karena permukaan genteng yang tidak rata akibat variasi bentuk. Hal ini menjadikan perlu pembuatan sampel yang rata dan memiliki nilai ukur antara panjang, lebar, dan tinggi yang proporsional. Alat yang digunakan pada pengambilan ini adalah alat uji tekan 1300 kN Hydraulic Hand Pump.

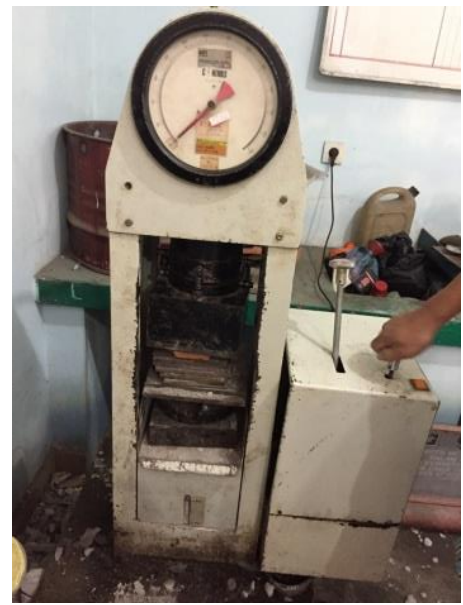

GAMBAR 2. Proses penekanan genteng dengan alat uji tekan $1300 \mathrm{kN}$

Hasil rata-rata pengujiannya dapat dilihat pada TABEL 3:

TABEL 3. Kuat Daya Tekan.

\begin{tabular}{ccc}
\hline No. & Komposisi Campuran & Kuat Daya Tekan (MPa) \\
\hline 1. & $0 \%$ & 48,84 \\
2. & $5 \%$ & 51,02 \\
3. & $10 \%$ & 47,92 \\
\hline
\end{tabular}

Data yang diperoleh pada uji kuat daya tekan ini tidak menunjukkan hasil yang saling terikat. Genteng dalam keadaan tanpa campuran memiliki kuat daya tahan 48,48 MPa. Besar kuat daya tekan pada campuran $0 \%$ tersebut di bawah nilai genteng dengan campuran 5\% yang memiliki kuat daya tekan 51,02 MPa. Pada campuran 10\% kuat daya tekan menurun di angka 47,92 MPa bahkan untuk campuran $15 \%$ terjadi penurunan yang signifikan yaitu di angka 15,63 MPa. Keadaan 0\% merupakan keadaan murni yang dihasilkan industri dalam kesehariannya. Penambahan penambahan campuran 
sebanyak 5\%, kuat daya genteng meningkat. Penambahan serbuk pada komposisi ini tidak cukup mengganggu gaya tarik antar molekul tanah yang bercampur serbuk kaca. Keberadaan serbuk kaca sebagai campuran sebanyak 5\% ini justru akan membantu mengisi ruang kosong akibat panas saat pembakaran sehingga menambah kekuatan genteng. Nilai campuran $5 \%$ menjadi nilai campuran maksimum untuk menghasilkan kuat daya tekan terbaik. Pada campuran $10 \%$ dan $15 \%$ menjadikan kondisi genteng menjadi rapuh. Keadaan ini disebabkan karena gaya tarik antar molekul tanah liat berkurang akibat keberadaan serbuk kaca yang tidak mampu untuk berikatan dengan tanah liat sehingga serbuk akan mengisi kekosongan rongga yang ada tanpa ada ikatan dengan tanah liat tersebut. Serbuk kaca yang berlebihan ini tetap mempertahan bentuk aslinya karena kaca merupakan bahan yang memiliki nilai konduktivitas termal tinggi. Semakin tinggi nilai konduktivitas termal suatu bahan maka bahan tersebut dapat menahan panas yang tinggi atas perubahan suhu yang meningkat. Berikut ini perbandingan peningkatan kuat daya tekan dalam bentuk grafik.

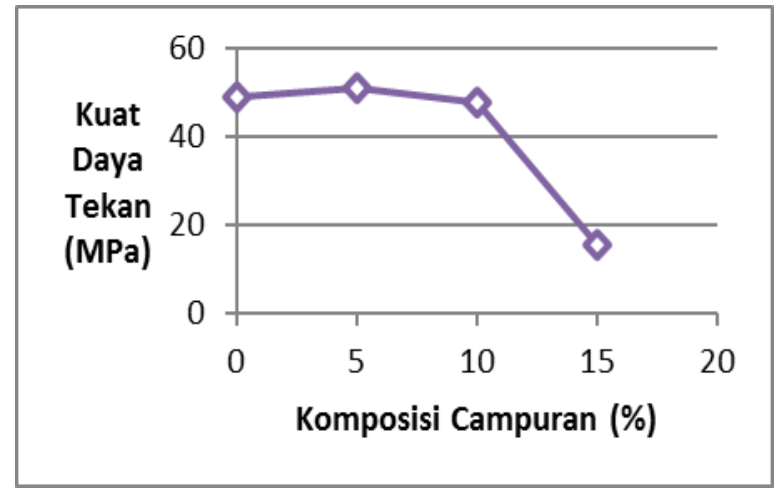

GAMBAR 3. Pengaruh komposisi campuran terhadap kuat daya tekan

Berikut ini rekapitulasi perbandingan banyaknya komposisi campuran terhadap besar daya serap air dan nilai kuat daya tekan.

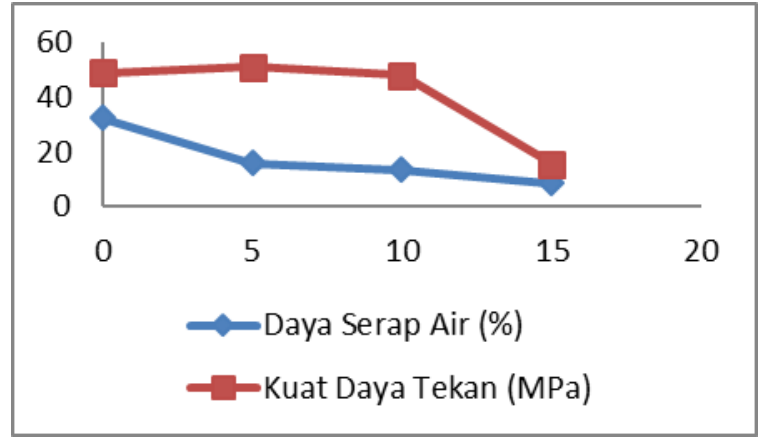

GAMBAR 4. Perbandingan nilai daya serap air dan kuat daya tekan genteng.

Data tersebut menyatakan bahwa semakin banyak komposisi campuran, maka persentase daya serap air genteng akan semakin kecil. Penurunan daya serap air ini menyatakan kualitas yang semakin baik. Kuat daya tekan genteng dapat meningkat dengan campuran yang tepat. Pada penelitian ini, penambahan komposisi 5\% meningkat sebesar 2,18 MPa dari keadaan normalnya. Pada penambahan $10 \%$ kuat daya tekan menurun $0,92 \mathrm{MPa}$ dan pada penambahan $15 \%$ kuat daya tekan menurun secara signifikan sebesar 33,21 MPa.

\section{SIMPULAN}

Kualitas genteng yang baik dapat dilihat dari segi daya serap air dan kuat daya tekan genteng. Kualitas tersebut dapat dipengaruhi karena komposisi bahan penyusun genteng. Penambahan serbuk 
kaca pada genteng tanah liat menjadikan porositas genteng semakin rapat sehingga daya serap air menjadi lebih kecil. Penambahan serbuk kaca juga mempengaruhi gaya tarik partikel tanah liat pada genteng sehingga pada komposisi tertentu dapat menambah kuat daya tekan tetapi pada komposisi yang berlebih justru mengurangi kuat daya tekan.

\section{UCAPAN TERIMAKASIH}

Puji Alloh. Terimakasih kepada Ayahanda dan Kakanda yang mendukung penelitian ini. Para dosen pembimbing. Latif Burhanuddin bin Khoirin yang berkenan membantu dalam pemrosesan pembuatan genteng di gudang produksinya. Kawan-kawan PPs UNNES Prodi Fisika yang menjadi teman berbagi dan mendiskusikan permasalahan.

\section{REFERENSI}

[1] F. O. Kolawole et al., "Corrugated Laterite Based Ceramic Roof Tile Stabilized with Cement," International Journal of Engineering and Technology Volume 4 No. 3, 2014, pp. 145-149

[2] M. El Ouahabi et al., "Potentiality of Clay Raw Materials from Northern Morocco in Ceramic Industry: Tetouan and Meknes Areas," Journal of Minerals and Materials Characterization and Engineering, 2014, 2, pp. 145-159

[3] Ismail A.M. Ibrahim et al., "Preparation of spherical silica nanoparticles: Stober silica," Journal of American Science, 2010;6(11), pp. 985-989

[4] J A. Delben et al., "Effect Of Glass Cullet On Thermal Properties of Kaolinite," Journal of Thermal Analysis and Calorimetry, 2007, 87(3), pp. 879-882.

[5] F. Albuquerque et al., "Thermal Transformations of Tile Clay Before And After Kaolin Addition," Journal of Thermal Analysis and Calorimetry, 2004, Vol. 75, Issue 2, pp. 677685 .

[6] Wibowo, Levin, "Pengaruh penambahan serbuk kaca dan water reducing high range admixtures terhadap kuat tekan dan modulus elastisitas pada beton," Yogyakarta, Tugas Akhir Program Studi Teknik Sipil Universitas Atma Jaya Yogyakarta, 2013.

[7] Sudjati, J. J., dkk., "Pengaruh Penggunaan Serbuk Kaca Sebagai Bahan Substitusi Agregat Halus Terhadap Sifat Mekanik Beton," Universitas Atma Jaya Yogyakarta, Jurnal teknik sipil Volume 13, No. 1, 2014, pp. 1-11

[8] Cheila Mothé and Maria Ambrósio, "Processes occurring during the sintering of porous ceramic materials by TG/DSC," Journal of Thermal Analysis and Calorimetry, CEP 21949900, 87(3), 2007, pp. 819-822.

[9] Sitanggang, E. S., dkk., "Studi Eksperimental Dan Simulasi Pengaruh Variasi Campuran High Density Polyetilena (Hdpe) dan Aspal Penetrasi 60/70 dengan Menggunakan Program Ansys 12," Departemen Teknik Mesin Fakultas Teknik Universitas Sumatera Utara, Jurnal Dinamis Vol. I, No.13, 2013, pp.9-17. 
